\title{
Serum uric acid to HDL-cholesterol ratio is a strong predictor of metabolic syndrome in type 2 diabetes mellitus
}

\author{
M. Zahid Kocak ${ }^{1}$ \\ (iD) Gulali Aktas ${ }^{1}$ \\ (iD) Edip Erkus ${ }^{1}$ \\ (iD) Isa Sincer ${ }^{2}$ \\ Burcin Atak ${ }^{1}$ \\ Tuba Duman ${ }^{1}$
}

1. Abant Izzet Baysal University, Faculty of Medicine, Department of Internal Medicine, Bolu, Turkey 2. Abant Izzet Baysal University, Faculty of Medicine, Department of Cardiology, Bolu, Turkey

http://dx.doi.org/10.1590/1806-9282.65.1.9

\section{SUMMARY}

OBJECTIVE: Metabolic syndrome (MS) is a clinical entity that associated with increased risk of type 2 Diabetes Mellitus (DM) and cardiovascular diseases. Serum uric acid levels are correlated MS criteria. We hypothesized whether a uric acid to HDL-cholesterol ratio (UHR) could predict diabetic regulation and presence of MS in type 2 diabetic subjects.

METHODS: Admissions of the subjects with type 2 DM to outpatient clinics of our institution were retrospectively analyzed. Study population grouped into well-controlled and poorly controlled diabetics according to the HbAtc level (cut off 7\%) and further grouped into type 2 DM with and without MS according to the presence of MS. UHR of study groups compared.

RESULTS: A hundred diabetic subjects enrolled. Mean UHR was significantly lower in well-controlled diabetics $(9.7 \pm 3.7 \%)$ compared to poorly controlled subjects (14 $\pm 5.4 \%)$ ( $p<0.001)$. Median UHR of diabetics with MS (13 (6-29) \%) was greater than that of the diabetics without MS (9 (3-16) \%) ( $p<0.001)$. UHR greater than $11 \%$ has $77 \%$ sensitivity and $60 \%$ specifity in predicting worse diabetic control (AUC: $0.752, p<0.001$ ) and a UHR greater than $10.6 \%$ has $83 \%$ sensitivity and $71 \%$ specifity in predicting MS (AUC: $0.839, p<0.001$ ). Sensitivity and specifity of UHR in predicting MS were better than most of the sensitivities and specifities of the five criteria of MS.

CONCLUSION: We suggest utilization of UHR in diagnosis of MS as a novel criteria. Nevertheless, prospective studies with larger population may make a better scientific evidence in that issue.

KEYWORDS: Metabolic syndrome. Diabetes mellitus, type 2. Uric acid. HDL-cholesterol.

\section{INTRODUCTION}

The term of metabolic syndrome (MS) first used by Haller and Hanefeld1 and was defined as combination of risk factors attributable to adverse events, such as, type 2 diabetes mellitus and cardiovascular diseases. Synonyms of MS are syndrome X, Reaven syndrome, dysmetabolic syndrome X, CHAOS, plurimetabolic syndrome, the deadly quartet, and insulin resistance syndrome2. Although definition of combined parameters of MS varies, a harmonized definition was accepted by International diabetes Federation (IDF), American Heart Association/National Heart, Lung and Blood Institute (AHA/NHLBI), the World Heart Federation, the International Atherosclerosis Society, and the International Associa-

DATE OF SUBMISSION: 27-May-2018

DATE OF ACCEPTANCE: 20-Jun-2018

CORRESPONDING AUTHOR: Gulali Aktas

Abant Izzet Baysal University Hospital, Department of Internal Medicine, 14280 Golkoy, Bolu, Turkey

Phone Number: +903742534656

Fax Number: +903742534615

E-mail:draliaktas@yahoo.com

mehmetzahidkocak@hotmail.com dr.ediperkus@gmail.com isasincer@yahoo.com burcinatak@hotmail.com doktortuuba@gmail.com 
tion for the Study of Obesity in 2009. Combination of three or more of 5 criteria (systolic blood pressure $\geq 130 \mathrm{mmHg}$ or diastolic blood pressure $\geq 85 \mathrm{mmHg}$ or treated, fating plasma glucose $\geq 100 \mathrm{mg} / \mathrm{dl}$ or treated, waist circumference $\geq 102 \mathrm{~cm}$ in men and $88 \mathrm{~cm}$ in women, HDL-cholesterol $<40 \mathrm{mg} / \mathrm{dl}$ in men and $<50 \mathrm{mg} / \mathrm{dl}$ in women, triglyceride $\geq 150 \mathrm{mg} / \mathrm{dl}$ ) make the diagnosis of MS.

Uric acid is synthesized by the enzyme xanthine oxidase during the metabolism of purines. High levels of serum uric acid contribute to development of adverse conditions3. Criteria of MS were found to be correlated with serum uric acid levels4-6. Population with higher uric acid levels are more likely to develop MS7.

Both type 2 diabetes mellitus (DM) and MS are considered as metabolic disorders. Presence of MS and its components are increased by elevated serum uric acid levels in type 2 diabetic subjects8.

According to strong relation between serum uric acid and type 2 DM and MS, we hypothesized whether a uric acid to HDL-cholesterol ratio (UHR) could predict diabetic regulation and presence of MS in type 2 diabetic subjects.

\section{METHOD}

Admissions of the subjects with type 2 DM to outpatient clinics of our institution between October 2017 and January 2018 were retrospectively analyzed, after institutional approval obtained. Type 2 diabetics were enrolled to the study. Exclusion criteria were as follows; pregnancy, active malignant disease, treatment with drugs that interfere with serum uric acid levels (thiazides, furosemide, acetyl salicylic acid, etc...) and on medications that may alter serum lipid levels (i.e. statins, fibrates, niacin). Subjects with established hemolytic conditions and end stage renal failure were also excluded.

Age, gender, height, weight, waist circumference, duration of diabetes mellitus, systolic blood pressure and diastolic blood pressure were recorded from the patient files and computerized database of our clinic. Body mass index (BMI) is calculated with division of weight (in kg) by square of height (in meters). Arithmetic mean of blood pressure that measured in consecutive 2 clinic visit in both arms were used as blood pressure measures.

Laboratory parameters, such as, fasting plasma glucose, blood urea, serum creatinine, total-choles- terol, LDL-cholesterol, HDL-cholesterol, triglyceride, serum uric acid, glomerular filtration rate (eGFR), glycated hemoglobin (HbA1c) were obtained from the same database and patient files. Plasma non HDL-cholesterol was simply calculated by following formula: total cholesterol- HDL cholesterol. UHR is calculated with division of serum uric acid by HDL cholesterol. Uric acid to non HDL cholesterol ratio is measured by the following formula: uric acid/non HDL cholesterol.

Patients grouped in to two groups according to HbA1c levels. Diabetics with HbA1c lower than 7\% were classified as well-controlled type 2 DM group and subjects with HbA1c equal to or greater than 7\% were classified as poorly controlled diabetics.

Study population were grouped into another two groups according to the presence of MS. Diagnosis of MS established according to the 2009 harmonized criteria of IDF, AHA/NHLBI, the World Heart Federation, the International Atherosclerosis Society, and the International Association for the Study of Obesity. Presence of three of five criteria (systolic blood pressure $\geq 130 \mathrm{mmHg}$ or diastolic blood pressure $\geq 85$ $\mathrm{mmHg}$ or treated, fasting plasma glucose $\geq 100 \mathrm{mg} / \mathrm{dl}$ or treated, waist circumference $\geq 102 \mathrm{~cm}$ in men and $88 \mathrm{~cm}$ in women, HDL-cholesterol $<40 \mathrm{mg} / \mathrm{dl}$ in men and $<50 \mathrm{mg} / \mathrm{dl}$ in women, triglyceride $\geq 150 \mathrm{mg} / \mathrm{dl}$ ) make the diagnosis of MS.

Data were analyzed by SPSS software. (SPSS 15.0; IBM Inc., Chicago, IL, USA). Distribution of the variables in study groups were conducted by Kolmogorov-Smirnov test. Homogenously distributed variables expressed as mean \pm standard deviation and compared with independent samples t test. Non-homogenously distributed variables were expressed as median (minimum-maximum) and compared with Mann Whitney U test. Categorical variables were compared in study groups with Chi-square test. Receiver Operative Characteristics (ROC) analyze used to determine cut-off values of UHR in predicting poorly controlled DM and in predicting MS. A Pearson's analyze was used to find out correlation between uric acid, HDL-cholesterol, triglyceride, BMI, waist circumference, UHR and HbA1c. Statistically significance was set on a $p$ value that lower than 0.05.

\section{RESULTS}

A total of 100 type 2 diabetic subjects enrolled to the study. Mean ages of the well-controlled and 
poorly controlled diabetics were $58.6 \pm 10$ years and $59.5 \pm 8.4$ years, respectively. Age difference was not statistically significant between well-controlled and poorly controlled type 2 DM groups $(\mathrm{p}=0.61) .22$ (55\%) of 40 in well-controlled group and $29(48.3 \%)$ of 60 in poorly controlled group were women. Gender was not statistically different among well-controlled and poorly controlled type 2 DM groups $(\mathrm{p}=0.51)$.

Height $(\mathrm{p}=0.97)$, body weight $(\mathrm{p}=0.17)$, waist circumference $(p=0.06)$, BMI $(p=0.12)$, systolic $(p=0.28)$ and diastolic $(\mathrm{p}=0.73)$ blood pressures were not significantly different between well-controlled and poorly controlled type 2 DM groups.

Serum uric acid was $4.9 \pm 1.4 \mathrm{mg} / \mathrm{dl}$ in well-controlled diabetics and $6 \pm 1.6 \mathrm{mg} / \mathrm{dl}$ in poorly controlled type 2 DM subjects $(p=0.001)$. HDL cholesterol of well-controlled type 2 DM group (50 [33-117] mg/dl) was significantly higher than that of the poorly controlled diabetic group (44 [25-73] mg/dl), $(\mathrm{p}<0.001)$. The mean UHRs of well-controlled and poorly controlled type 2 DM groups were $9.7 \pm 3.7 \%$ and $14 \pm$ $5.4 \%$, respectively. The UHR difference was statis- tically significant $(\mathrm{p}<0.001)$. Comparison of clinical and laboratory data of the well-controlled and poorly controlled diabetic subjects is summarized in table 1 .

A ROC analyze performed to determine sensitivity and specifity of UHR in selecting poorly control in type 2 DM. UHR greater than $11 \%$ has $77 \%$ sensitivity and $60 \%$ specifity in predicting worse diabetic control (AUC: 0.752, $\mathrm{p}<0.001$ ).

Study population further grouped according to the existence of MS. There were 63 subjects with MS and 37 subjects without MS. Mean ages of the subjects with and without MS were $59.6 \pm 9.1$ years and $58.4 \pm 9.2$ years, respectively. Age difference was not statistically significant between groups $(\mathrm{p}=0.54)$. $29(46 \%)$ of 63 in type 2 DM with MS group and 22 (59.5\%) of 37 in type 2 DM without MS group were women. Gender was not significantly different between groups $(\mathrm{p}=0.20)$. A total of 36 subjects were on antihypertensive treatment (28 in diabetics with MS and 8 in diabetics without MS groups).

Height $(\mathrm{p}=0.41)$, BMI $(\mathrm{p}=0.07)$, duration of type 2 DM $(p=0.93)$, blood urea $(p=0.92)$, serum creatinine

TABLE 1: COMPARISON OF CLINICAL AND LABORATORY DATA OF THE WELL-CONTROLLED AND POORLY CONTROLLED TYPE 2 DM GROUPS

\begin{tabular}{|c|c|c|c|c|}
\hline & & Well-controlled Type 2 DM & Poorly controlled type 2 DM & $\mathrm{p}$ \\
\hline \multirow[t]{2}{*}{ Gender } & Men $(n(\%))$ & $18(45)$ & $31(51,7)$ & \multirow{2}{*}{0.51} \\
\hline & Women (n (\%)) & $22(55)$ & $29(48,3)$ & \\
\hline & & \multicolumn{2}{|l|}{ Mean \pm Standard Deviation } & \\
\hline \multicolumn{2}{|c|}{ Age (years) } & $58,6 \pm 10$ & $59,5 \pm 8,4$ & 0.61 \\
\hline \multicolumn{2}{|c|}{ Height (m) } & $1,62 \pm 0,1$ & $1,63 \pm 0,1$ & 0.97 \\
\hline \multicolumn{2}{|c|}{ Weight (kg) } & $80 \pm 15$ & $84 \pm 14$ & 0.17 \\
\hline \multicolumn{2}{|c|}{ Total cholesterol (mg/dl) } & $185 \pm 44$ & $214 \pm 45$ & 0.003 \\
\hline \multicolumn{2}{|c|}{ Non HDL cholesterol (mg/dl) } & $132 \pm 42$ & $169 \pm 46$ & $<0.001$ \\
\hline \multicolumn{2}{|c|}{ LDL cholesterol (mg/dl) } & $106 \pm 33$ & $125 \pm 38$ & 0.01 \\
\hline \multicolumn{2}{|c|}{ UHR (\%) } & $9,7 \pm 3,7$ & $14 \pm 5,4$ & $<0.001$ \\
\hline \multicolumn{2}{|c|}{ Uric acid (mg/dl) } & $4,9 \pm 1,4$ & $6 \pm 1,6$ & 0.001 \\
\hline \multicolumn{2}{|c|}{$\mathrm{eGFR}\left(\mathrm{mL} / \mathrm{min} / 1.73 \mathrm{~m}^{2}\right)$} & $86 \pm 14$ & $81 \pm 14$ & 0.08 \\
\hline \multirow{2}{*}{\multicolumn{2}{|c|}{ Urea (mg/dl) }} & $30,4 \pm 9,8$ & $34,8 \pm 12,7$ & 0.07 \\
\hline & & \multicolumn{2}{|l|}{ Median (Min- Max) } & \\
\hline \multicolumn{2}{|c|}{$\mathrm{SBP}(\mathrm{mmHg})$} & $130(100-180)$ & $130(100-180)$ & 0.28 \\
\hline \multicolumn{2}{|c|}{$\mathrm{DBP}(\mathrm{mmHg})$} & $80(70-110)$ & $80(50-105)$ & 0.73 \\
\hline \multicolumn{2}{|c|}{ Waist circumference $(\mathrm{cm})$} & $100(77-128)$ & $105(81-144)$ & 0.06 \\
\hline \multicolumn{2}{|c|}{ Fasting blood glucose (mg/dl) } & $119(89-219)$ & $190(64-466)$ & $<0.001$ \\
\hline \multicolumn{2}{|c|}{ Triglyceride (mg/dl) } & $131(46-369)$ & $174(59-615)$ & 0.04 \\
\hline \multicolumn{2}{|c|}{ HDL-cholesterol (mg/dl) } & $50(33-117)$ & $44(25-73)$ & $<0.001$ \\
\hline \multicolumn{2}{|c|}{ Uricacid to non-HDL ratio (\%) } & $4(1-10)$ & $4(1-8)$ & 0.4 \\
\hline \multicolumn{2}{|c|}{$\mathrm{BMI}\left(\mathrm{kg} / \mathrm{m}^{2}\right)$} & $29,4(22,3-47)$ & $30,4(21,6-49,4)$ & 0.12 \\
\hline \multicolumn{2}{|c|}{ Duration of DM (years) } & $3,5(1-20)$ & $8(1-25)$ & 0.01 \\
\hline \multicolumn{2}{|c|}{ HbA1c (\%) } & $6,7(6,1-6,9)$ & $9,5(7,1-15,5)$ & $<0.001$ \\
\hline \multicolumn{2}{|c|}{ Creatinine (mg/dl) } & $0,81(0,63-1,2)$ & $0,88(0,4-1,2)$ & 0.04 \\
\hline
\end{tabular}


( $\mathrm{p}=0.90)$, total cholesterol $(\mathrm{p}=0.06)$, LDL cholesterol $(p=0.08)$, and eGFR $(p=0.24)$ were not significantly different between type $2 \mathrm{DM}$ with and without MS groups.

Serum uric acid was $6(2.6-9.6) \mathrm{mg} / \mathrm{dl}$ in diabetics with MS and 4.8 (2.1-7.7) $\mathrm{mg} / \mathrm{dl}$ in diabetics without MS, reaching the difference significance level $(p<0.001)$. HDL cholesterol of diabetics with MS group (44 [25-73] mg/dl) was significantly lower than that of the diabetics without MS group (54 [40-117] $\mathrm{mg} / \mathrm{dl}),(\mathrm{p}<0.001)$. The median UHRs of diabetics with and without MS groups were 13 (6-29) \% and 9 (3-16) $\%$, respectively. The UHR difference between groups was statistically significant $(\mathrm{p}<0.001)$. Comparison of clinical and laboratory data of the diabetics with and without MS groups is summarized in table 2.

A ROC analyze performed to determine sensitivity and specifity of uric acid, UHR, uric acid to nonHDL cholesterol ratio, SBP (at $\geq 130 \mathrm{mmHg}$ level), DBP (at $\geq 85 \mathrm{mmHg}$ level), triglyceride (at $\geq 150 \mathrm{mg} /$ $\mathrm{dl}$ level), waist circumference (at levels of $\geq 102 \mathrm{~cm}$ for men and $\geq 88 \mathrm{~cm}$ for women) and HDL cholesterol (at $<40 \mathrm{mg} / \mathrm{dl}$ for men and $<50 \mathrm{mg} / \mathrm{dl}$ for women) levels in selecting subjects with MS. UHR greater than $10,6 \%$ has $83 \%$ sensitivity and $71 \%$ specifity in predicting MS (AUC: $0.839, \mathrm{p}<0.001)$. Figure 1 shows the ROC curves of study parameters in predicting MS.

Pearson's correlation analysis showed that UHR was positively correlated with waist circumference $(\mathrm{r}=0.32, \mathrm{p}=0.001)$, fasting blood glucose $(\mathrm{r}=0.39$, $\mathrm{p}<0.001)$, triglyceride $(\mathrm{r}=0.59, \mathrm{p}<0.001)$ and HbA1c $(\mathrm{r}=0.54, \mathrm{p}<0.001)$ levels. Neither body weight $(\mathrm{r}=0.19$, $\mathrm{p}=0.06)$, nor BMI $(\mathrm{r}=0.13, \mathrm{p}=0.21)$ were correlated with UHR. Additionally, UHR was not correlated with SBP $(r=0.15, p=0.13)$ and DBP $(r=0.06, p=0.58)$, either.

\section{DISCUSSION}

In present study, we showed that UHR predicts MS better than all established criteria of this clinical entity. Another important finding of our report

TABLE 2: COMPARISON OF CLINICAL AND LABORATORY DATA OF THE DIABETICS WITH AND WITHOUT METABOLIC SYNDROME

\begin{tabular}{|c|c|c|c|c|}
\hline & & $\begin{array}{l}\text { Type } 2 \text { DM with metabolic } \\
\text { syndrome }\end{array}$ & $\begin{array}{l}\text { Type } 2 \text { DM without metabol- } \\
\text { ic syndrome }\end{array}$ & $\mathrm{p}$ \\
\hline \multirow[t]{2}{*}{ Gender } & Men $(n(\%))$ & $34(54)$ & $15(40,5)$ & \multirow{2}{*}{0.20} \\
\hline & Women (n (\%)) & $29(46)$ & $22(59,5)$ & \\
\hline & & \multicolumn{2}{|l|}{ Mean \pm Standard Deviation } & \\
\hline \multicolumn{2}{|c|}{ Age (years) } & $59,6 \pm 9,1$ & $58,4 \pm 9,2$ & 0.54 \\
\hline \multicolumn{2}{|c|}{ Height (m) } & $1,63 \pm 0,1$ & $1,62 \pm 0,1$ & 0.41 \\
\hline \multicolumn{2}{|c|}{ Weight (kg) } & $84.7 \pm 14.5$ & $78.2 \pm 13.8$ & 0.03 \\
\hline \multicolumn{2}{|c|}{ Waist circumference $(\mathrm{cm})$} & $109 \pm 11$ & $95 \pm 10$ & $<0.001$ \\
\hline \multicolumn{2}{|c|}{ Total cholesterol (mg/dl) } & $209 \pm 48$ & $191 \pm 42$ & 0.06 \\
\hline \multicolumn{2}{|c|}{ Non HDL cholesterol (mg/dl) } & $166 \pm 49$ & $134 \pm 38$ & 0.001 \\
\hline \multicolumn{2}{|c|}{ LDL cholesterol (mg/dl) } & $123 \pm 39$ & $109 \pm 32$ & 0.08 \\
\hline \multicolumn{2}{|c|}{ Creatinine (mg/dl) } & $0,86 \pm 0,17$ & $0,86 \pm 0,15$ & 0.90 \\
\hline \multirow{2}{*}{\multicolumn{2}{|c|}{$\mathrm{eGFR}\left(\mathrm{mL} / \mathrm{min} / 1.73 \mathrm{~m}^{2}\right)$}} & $81 \pm 14$ & $85 \pm 14$ & 0.24 \\
\hline & & \multicolumn{2}{|l|}{ Median (Min- Max) } & \\
\hline \multicolumn{2}{|c|}{$\mathrm{SBP}(\mathrm{mmHg})$} & $140(110-180)$ & $125(100-170)$ & $<0.001$ \\
\hline \multicolumn{2}{|c|}{$\mathrm{DBP}(\mathrm{mmHg})$} & $80(50-110)$ & $80(60-105)$ & 0.01 \\
\hline \multicolumn{2}{|c|}{ UHR (\%) } & $13(6-29)$ & $9(3-16)$ & $<0.001$ \\
\hline \multicolumn{2}{|c|}{ Fasting blood glucose (mg/dl) } & $156(72-466)$ & $129(62-377)$ & 0.03 \\
\hline \multicolumn{2}{|c|}{ Triglyceride (mg/dl) } & $176(59-615)$ & $112(46-456)$ & $<0.001$ \\
\hline \multicolumn{2}{|c|}{ HDL-cholesterol (mg/dl) } & $44(25-73)$ & $54(40-117)$ & $<0.001$ \\
\hline \multicolumn{2}{|c|}{ Uricacid to non-HDL ratio (\%) } & $4(1-10)$ & $4(1-7)$ & 0.94 \\
\hline \multicolumn{2}{|c|}{$\mathrm{BMI}\left(\mathrm{kg} / \mathrm{m}^{2}\right)$} & $31(23-49)$ & $28(22-48)$ & 0.07 \\
\hline \multicolumn{2}{|c|}{ Duration of DM (years) } & $6(1-20)$ & $6(1-25)$ & 0.93 \\
\hline \multicolumn{2}{|c|}{ HbA1c (\%) } & $8,8(6,2-15,5)$ & $6,8(6,1-14,2)$ & 0.003 \\
\hline \multicolumn{2}{|c|}{ Uric acid (mg/dl) } & $6(2,6-9,6)$ & $4,8(2,1-7,7)$ & $<0.001$ \\
\hline \multicolumn{2}{|c|}{ Urea (mg/dl) } & $32(13-82)$ & $32(13-58)$ & 0.92 \\
\hline
\end{tabular}




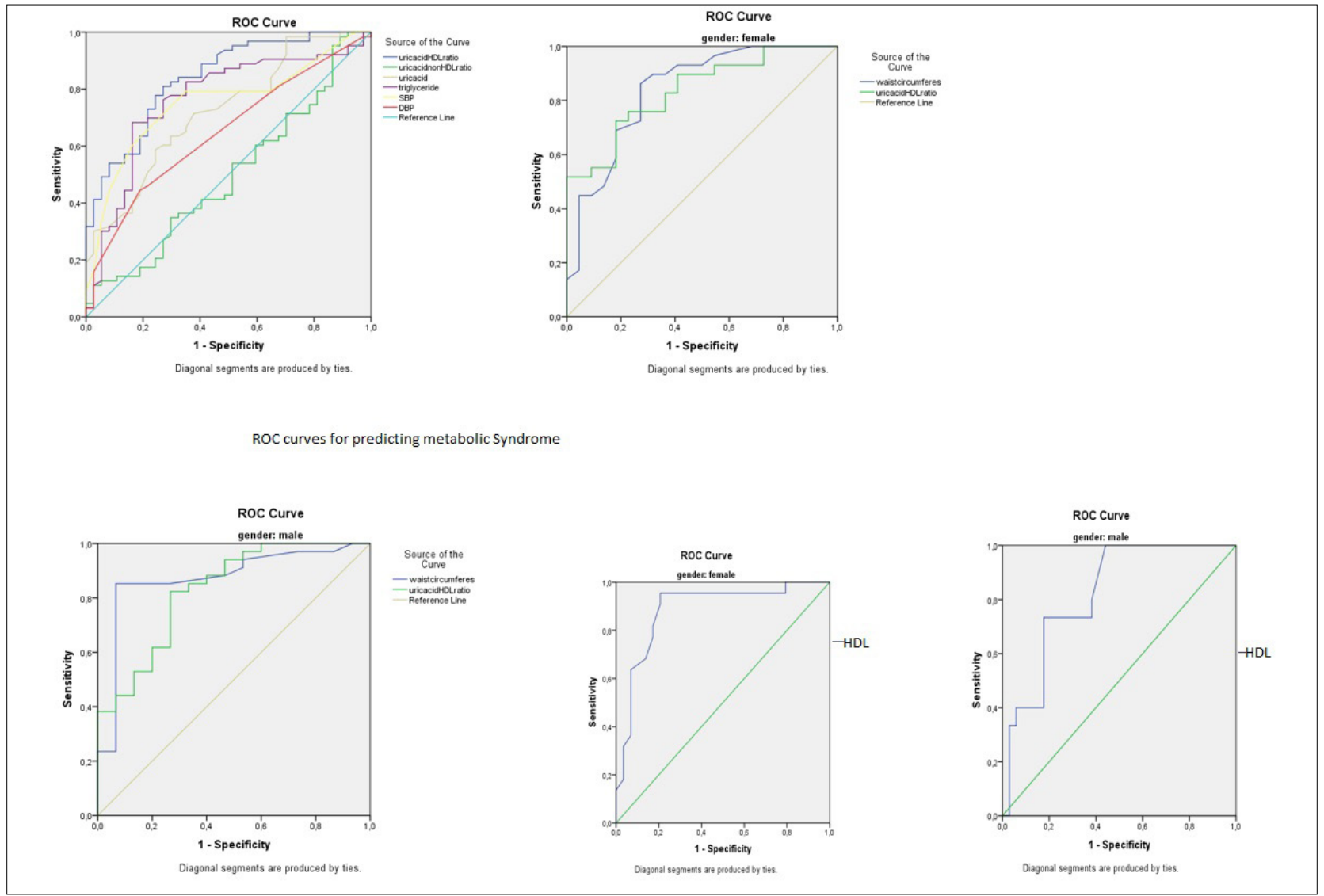

is that UHR has high sensitivity and specifity as a marker of diabetic control.

Association between MS and serum uric acid levels is well established in the literature. In 2007, authors identified a substantial association between serum uric acid and MS prevalence ${ }^{9}$. Chang et al. ${ }^{7}$ reported that elevated serum uric acid levels were contributed to higher risk of MS. Moreover, elevated serum uric acid has been proposed as a risk factor for $\mathrm{MS}^{\mathbf{1 0}}$. In present study, UHR was better than uric acid alone as a marker of MS.

Evidence in literature suggest that serum uric acid levels was in association with each one diagnostic criteria of the $\mathrm{MS}^{\mathbf{1 0}}$. Risk of development of type $2 \mathrm{DM}$ is increased in subjects with elevated serum uric acid levels ${ }^{11,12}$. Indeed, increased uric acid was associated with worse diabetic control in type 2 diabetic subjects in a recent study ${ }^{13}$. On the other hand, insulin resistance plays a pivotal role in development of both MS and type 2 DM. Therefore, such an association between high uric acid and development of type 2 DM and MS. Similar to the literature knowledge, since it is a uric acid derived indice, UHR was positively and strongly correlated with fasting plasma glucose and HbA1c levels in present study.

According to the Nakanishi et al.5's study, not only type $2 \mathrm{DM}$ but also hypertension was more common in subjects with higher serum uric acid ${ }^{14}$. In contrary, hypertension was not associated with high uric acid levels in a recent study by Wang et al. ${ }^{15}$. In concordance, there was no significant correlation between blood pressure and UHR levels in our report.

Significant positive correlation between UHR and triglyceride and inverse correlation between UHR and HDL-cholesterol levels in present study, suggest the previous results in literature. Uric acid was found to be positively correlated with serum triglyceride and negatively correlated with HDL-cholesterol levels in Peng et al. ${ }^{16}$ 's report. However, increased triglyceride and low HDL levels were not associated with increased risk of hyperuricemia in a Chinese study $^{\mathbf{1 5}}$. Correlation between UHR and triglyceride was more significant and stronger than the correlation between uric acid and triglyceride in our study. Furthermore, inverse correlation between UHR and HDL was more significant and stronger than the correlation between uric acid and HDL.

Obesity is also associated with serum uric acid 
levels through increased production pathways ${ }^{17}$. However, literature data about association between uric acid levels and waist circumference, a marker of central obesity, is conflicting. Waist circumference was not associated with hyperuricemia in a recent study $^{15}$. On the other hand, a significant and positive correlation reported between waist circumference and uric acid levels in another Chinese study $^{18}$. We found that correlation between uric acid and waist circumference was weaker than the correlation between UHR and waist circumference in this report.

Uric acid levels increase in chronic kidney disease. However, serum creatinine and GFR values of subjects with and without MS were not different in present report. Thus, elevated UHR in subjects with MS only reflect the presence of this clinical entity.

Results of the present study showed that, in predicting MS, UHR (at a cut of equal to or greater than $10,6 \%$ ) had greater sensitivity than uric acid level (at a cut off equal to or higher than $5 \mathrm{mg} / \mathrm{dl}$ ), triglyceride level (at a cut off equal to or higher than $150 \mathrm{mg} /$ dl), SBP (at a cut off equal to or greater than 130 $\mathrm{mmHg}$ ), DBP (at a cut off equal to or greater than of $85 \mathrm{mmHg}$ ), waist circumference in men (at a cut off equal to or higher than $102 \mathrm{~cm}$ ) and HDL in men (at a cut off lower than $40 \mathrm{mg} / \mathrm{dl}$ ). Only waist circumference in women (at a cut off equal to or higher than $88 \mathrm{~cm}$ ) and HDL in women (at a cut off lower than 50 $\mathrm{mg} / \mathrm{dl}$ ) have higher sensitivity than UHR in predicting MS. Specifity of UHR (at a cut of equal to or greater than 10,6\%) in selecting MS was higher than uric acid level (at a cut off equal to or higher than $5 \mathrm{mg} / \mathrm{dl}$ ), SBP (at a cut off equal to or greater than $130 \mathrm{mmHg}$ ), HDL in men (at a cut off lower than $40 \mathrm{mg} / \mathrm{dl}$ ) and waist circumference in women (at a cut off equal to or higher than $88 \mathrm{~cm}$ ). Triglyceride level (at a cut off equal to or higher than $150 \mathrm{mg} / \mathrm{dl}$ ), DBP (at a cut off equal to or greater than of $85 \mathrm{mmHg}$ ), HDL in women (at a cut off lower than $50 \mathrm{mg} / \mathrm{dl}$ ) and waist circumference in men (at a cut off equal to or higher than $102 \mathrm{~cm}$ ) have higher specifity than UHR in selecting subjects with MS. Unlike waist circumference and HDL, it was not affected by gender, therefore, we are proud to introduce UHR as a novel and useful criteria in the diagnosis of MS.

Limitations of present study are retrospective design which could cause selection bias, and relatively small size of study cohort. However, to our knowledge, it is the first study in literature that reported UHR as a predictor of MS and worse diabetic control in type $2 \mathrm{DM}$.

\section{CONCLUSION}

Present study suggest that utilization of UHR is a useful tool in diagnosis of MS as a novel criteria. Nevertheless, prospective studies with larger population may make a better scientific evidence in that issue.

Conflict of interest: None

Sources of Funding: None

\section{RESUMO}

CONTEXTO E OBJETIVO: A síndrome metabólica (SM) é uma entidade clínica associada ao aumento do risco de diabetes mellitus tipo 2 (DM) e doenças cardiovasculares. Os níveis séricos de ácido úrico estão correlacionados com os critérios estabelecidos de EM. Uma vez que DM tipo 2 e MS são distúrbios metabólicos, nós hipotetizamos se uma relação ácido úrico para HDL-colesterol (UHR) poderia predizer a regulação diabética e a presença de MS em diabéticos tipo 2.

MÉTODOS: As admissões dos sujeitos com DM tipo 2 aos ambulatórios de nossa instituição foram analisadas retrospectivamente. A população do estudo agrupou-se em diabéticos bem controlados e mal controlados, de acordo com o nível de HbA7c (corte de 7\%) e posteriormente agrupados em DM tipo 2 com e sem EM de acordo com a presença de EM. UHR dos grupos de estudo comparados.

RESULTADOS: Um total de 100 indivíduos diabéticos tipo 2 inscritos no estudo. A média UHR foi significativamente menor em diabéticos bem controlados $(9,7 \pm 3,7 \%)$ em comparação com indivíduos com DM tipo 2 mal controlada $(14 \pm 5,4 \%)(p<0,001)$. A mediana da UAR de diabéticos com EM (13 (6-29)\%) foi maior que a dos diabéticos sem SM (9 (3-16)\%) ( $p<0,001)$. Um UHR maior que 11\% tem $77 \%$ de sensibilidade e $60 \%$ de especificidade em predizer um pior controle diabético (AUC: 0,762, $p<0,001$ ) e um UHR maior que 10,6\% tem 83\% de sensibilidade e 71\% de especificidade em prever MS (AUC: 0,839, $p<0,001$ ). A sensibilidade e especificidade de UHR em predizer MS foram melhores do que a maioria das sensibilidades e especificidades dos cinco critérios de MS.

CONCLUSÃo: Sugerimos a utilização da UHR no diagnóstico da SM como um novo critério. No entanto, estudos prospectivos com maior população podem fazer uma melhor evidência científica nessa questão. 


\section{REFERENCES}

1. Haller $\mathrm{H}$, Hanefeld M. Synoptische betrachtung metabolischer risikofaktoren. Lipidstoffwechselstörungen. 1975;254-64.

2. Samson SL, Garber A). Metabolic syndrome. Endocrinol Metab Clin North Am. 2014;43(1):1-23

3. Nejatinamini S, Ataie-Jafari A, Qorbani M, Nikoohemat S, Kelishadi R, Asayesh $\mathrm{H}$, et al. Association between serum uric acid level and metabolic syndrome components. J Diabetes Metab Disord. 2015;14(1):1-7.

4. Sundström |, Sullivan L, D'Agostino RB, Levy D, Kannel WB, Vasan RS. Relations of serum uric acid to longitudinal blood pressure tracking and hypertension incidence. Hypertension. 2005;45(1):28-33.

5. Nakanishi N, Okamoto M, Yoshida H, Matsuo Y, Suzuki K, Tatara K. Serum uric acid and risk for development of hypertension and impaired fasting glucose or type II diabetes in Japanese male office workers. Eur J Epidemiol. 2003;18(6):523-30.

6. Shih M-H, Lazo M, Liu S-H, Bonekamp S, Hernaez R, Clark JM. Association between serum uric acid and nonalcoholic fatty liver disease in the US population. J Formos Med Assoc. 2015;114(4):314-20.

7. Chang $\mid \mathrm{B}, \mathrm{Chen} Y \mathrm{Y}$, Hung $\mathrm{Y} \mid$, Hsieh $\mathrm{CH}$, Lee $\mathrm{CH}$, Pei $\mathrm{D}$, et al. The role of uric acid for predicting future metabolic syndrome and type 2 diabetes in older people. J Nutr Health Aging. 2017;21(3):329-35.

8. Bonakdaran S, Kharaqani B. Association of serum uric acid and metabolic syndrome in type 2 diabetes. Curr Diabetes Rev. 2014;10(2):113-7.

9. Choi HK, Ford ES. Prevalence of the metabolic syndrome in individuals with hyperuricemia. Am J Med. 2007;120(5):442-7.

10. Chen YY, Kao TW, Yang HF, Chou CW, Wu C), Lai CH, et al. The association of uric acid with the risk of metabolic syndrome, arterial hyperten- sion or diabetes in young subjects: an observational study. Clin Chim Acta. 2018;478:68-73.

11. Krishnan E, Pandya BJ, Chung L, Hariri A, Dabbous O. Hyperuricemia in young adults and risk of insulin resistance, prediabetes, and diabetes: a 15-year follow-up study. Am J Epidemiol. 2012;176(2):108-16.

12. Woyesa SB, Hirigo AT, Wube TB. Hyperuricemia and metabolic syndrome in type 2 diabetes mellitus patients at Hawassa university comprehensive specialized hospital, South West Ethiopia. BMC Endocr Disord. 2017; 17(1):76

13. Duman TT, Kocak MZ, Atak BM, Erkus E. Serum uric acid is correlated with HbA1c levels in type 2 diabetes mellitus. Exp Biomed Res. 2018;1(1):6-9.

14. Kelliny C, William J, Riesen W, Paccaud F, Bovet P. Metabolic syndrome according to different definitions in a rapidly developing country of the African region. Cardiovasc Diabetol. 2008;7(1):1-11.

15. Wang J, Chen RP, Lei L, Song QQ, Zhang RY, Li YB, et al. Prevalence and determinants of hyperuricemia in type 2 diabetes mellitus patients with central obesity in Guangdong Province in China. Asia Pac J Clin Nutr. 2013;22(4):590-8.

16. Peng TC, Wang CC, Kao TW, Chan JY, Yang YH, Chang YW, et al. Relationship between hyperuricemia and lipid profiles in US adults. Biomed Res Int. 2015;2015(2015):127596.

17. Hikita M, Ohno I, Mori $Y$, Ichida K, Yokose T, Hosoya T. Relationship between hyperuricemia and body fat distribution. Intern Med. 2007;46(17):1353-8.

18. Chen LY, Zhu WH, Chen ZW, Dai HL, Ren JJ, Chen JH, et al. Relationship between hyperuricemia and metabolic syndrome. I Zhejiang University Science B. 2007:8(8):593-8. 